\title{
Houston-Galveston Bay Area, Texas, From Space- A New Tool for Mapping Land Subsidence
}

Interferometric Synthetic Aperture Radar (InSAR) is a powerful new tool that uses radar signals to measure displacement (subsidence and uplift) of the Earth's crust at an unprecedented level of spatial detail and high degree of measurement resolution.

The Houston-Galveston Bay area, possibly more than any other metropolitan area in the United States, has been adversely affected by land subsidence. Extensive subsidence, caused mainly by ground-water pumping but also by oil and gas extraction, has increased the frequency of flooding, caused extensive damage to industrial and transportation infrastructure, motivated major investments in levees, reservoirs, and surfacewater distribution facilities, and caused substantial loss of wetland habitat. Ongoing patterns of subsidence in the Houston area have been carefully monitored using borehole extensometers, Global Positioning System (GPS) and conventional spirit-leveling surveys, and more recently, an emerging technology-Interferometric Synthetic Aperture Radar (InSAR) - which enables development of spatially-detailed maps of land-surface displacement over broad areas.

This report, prepared by the U.S. Geological Survey (USGS) in cooperation with the U.S. Fish and Wildlife Service, briefly summarizes the history of subsidence in the area and the local consequences of subsidence and describes the use of InSAR as one of several tools in an integrated subsidence-monitoring program in the area.

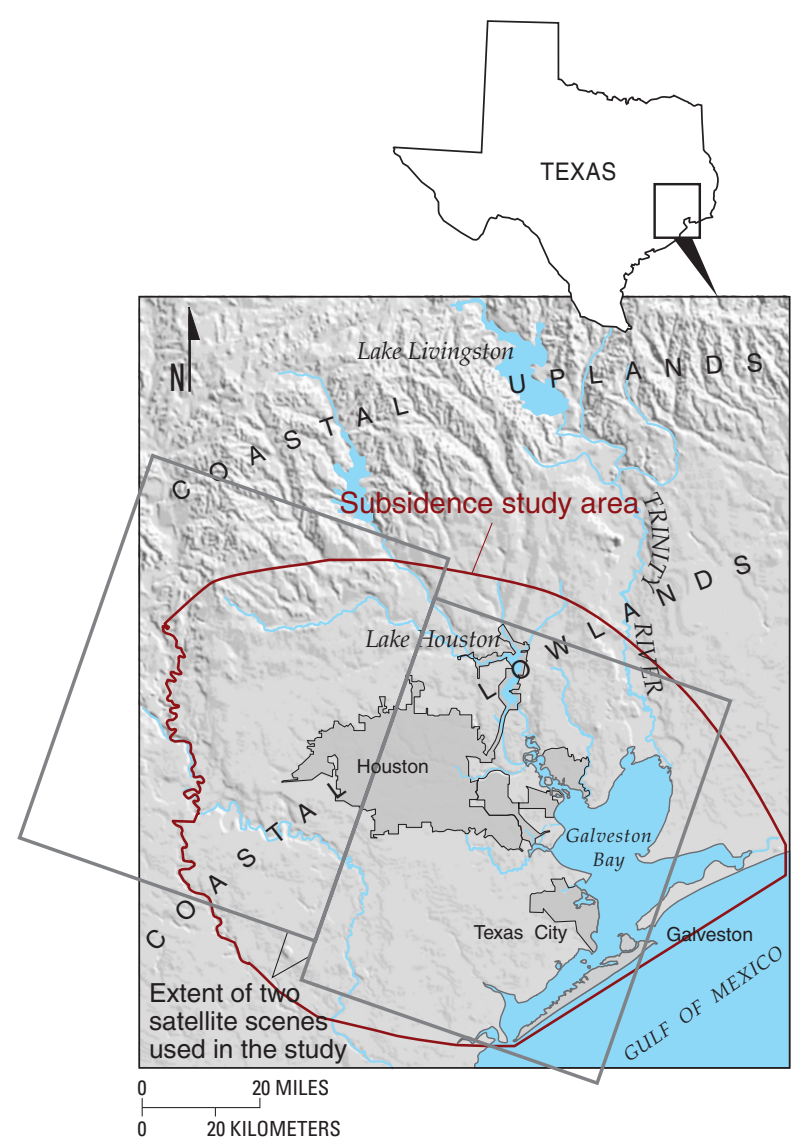

Figure 1. Subsidence study area and extent of two satellite scenes, Houston-Galveston Bay area, Texas.
Land subsidence in the Houston-Galveston Bay area (fig. 1) first occurred in the early 1900s in areas where ground water, oil, and gas were extracted. Subsidence continued throughout the 20th century, primarily owing to compaction of the aquifer systems caused by ground-water pumpage and the associated groundwater-level declines. More than 10 feet (ft) of subsidence was measured near Pasadena during 1906-95, and almost 3,200 square miles $\left(\mathrm{mi}^{2}\right)$ had subsided more than $1 \mathrm{ft}$ (fig. 2) The patterns of subsidence in the area closely follow the temporal and spatial pat- terns of subsurface fluid extraction. Subsidence caused by oil and gas extraction typically is restricted locally to the field of production such as at Goose Creek oil field, in contrast to the regionalscale subsidence typically caused by ground-water pumpage (Coplin and Galloway, 1999).

Until 1942, essentially all water demand in Houston was supplied by local ground water. By 1943, subsidence had begun to affect a large part of the Houston area, although the amounts 


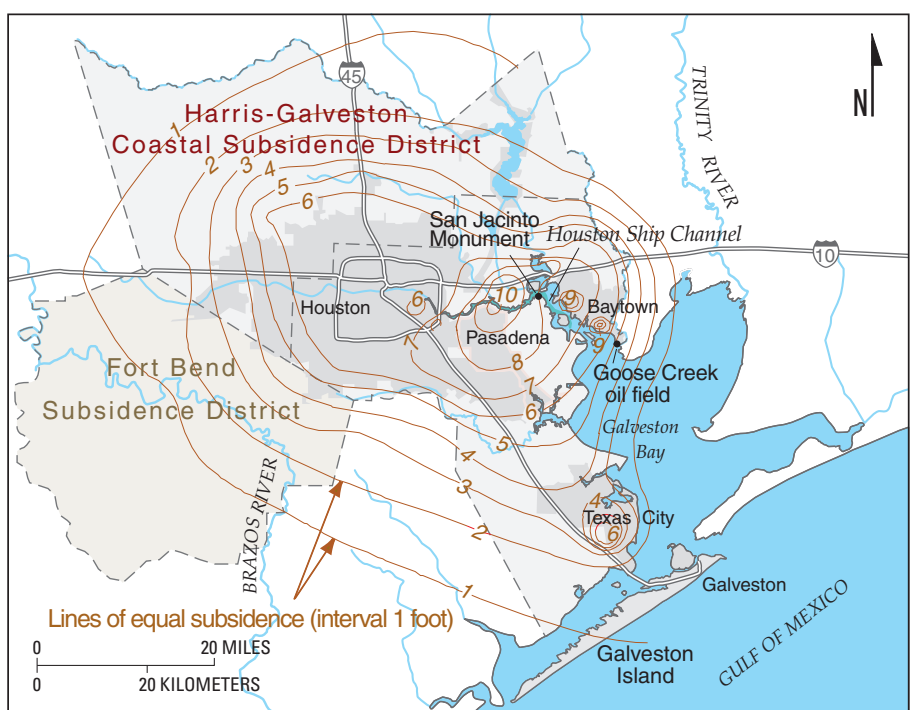

Figure 2. Extent of subsidence in the Houston-Galveston Bay area during 1906-95.

generally were less than $1 \mathrm{ft}$. By the mid-1970s, $6 \mathrm{ft}$ or more of subsidence had occurred throughout an area along the Houston Ship Channel between Baytown and Houston as a result of declining ground-water levels caused by increased ground-water pumpage associated with rapid industrial expansion in the area.

Growing awareness of subsidencerelated problems on the part of community and business leaders prompted the 1975 Texas Legislature to create the HarrisGalveston Coastal Subsidence District (fig. 2), “. . . for the purpose of ending subsidence which contributes to, or precipitates, flooding, inundation, and overflow of any area within the District ...." (State of Texas, 1975, p. 672). This unprecedented subsidence district was authorized to issue (or refuse) well permits, promote water conservation and education, and promote conversion from ground-water supply to surface-water supply, but the district was forbidden to own property such as watersupply and conveyance facilities.

The initial Subsidence District regulatory plan (1976) was designed to have "... an immediate impact in the area where most of the subsidence had taken place ...." (Harris-Galveston Coastal Subsidence District, 1999, p. 3). The plan generally has succeeded in its primary objective: Since the late 1970s, subsidence largely has been abated along the ship channel and in the Baytown and Pasadena areas in the coastal lowlands south and east of Houston owing to a reduction in groundwater pumpage (fig. 3). Surface water from Lake Livingston on the Trinity River (fig. 1) was used as a source of water for industrial use in the area of the Houston Ship Channel (fig. 2). The additional water supplied by Lake Livingston was sufficient to appreciably reduce ground-water use and ultimately led to a recovery of water levels over a large area. However, as subsidence in the coastal area was stabilizing, subsidence inland was continuing, especially in the rapidly growing areas north and west of Houston that mostly are still dependent on ground water (fig. 3).

In this region ground-water levels in the Evangeline aquifer declined more than $100 \mathrm{ft}$ during 1977-97, and $2.3 \mathrm{ft}$ of subsidence was measured near Addicks (fig. 3) between 1978 and 1995 (Coplin and others, 2001). During the 1989 legislative session, the Fort Bend Subsidence District (fig. 2) was created to manage and control subsidence in Fort Bend County.

\section{Consequences of Land Subsidence}

Land subsidence in the Houston-Galveston Bay area has increased the frequency and severity of flooding (fig. 4). In this low-lying coastal environment, more than $10 \mathrm{ft}$ of subsidence (fig. 2) has shifted the position of the coastline and changed the distribution of wetlands and aquatic vegetation. In fact, the San Jacinto Battleground State Historical Park, site of the battle that won Texas independence and commemorated with the San Jacinto Monument (fig. 2), is now partly submerged. At many localities in the Houston area, ground-water pumpage and subsidence also have induced fault movement. Since the late 1930s, 86 active faults in the Houston area have offset the land surface and damaged buildings and highways in the metropolitan area (Holzer and Gabrysch, 1987; Coplin and Galloway, 1999).

Near the coast, the result of land subsidence is an apparent increase in sea level, or a relative sea-level rise - the net effect of global sea-level rise and regional land subsidence in the coastal zone. The sea level is in fact rising because of regional and global processes. The

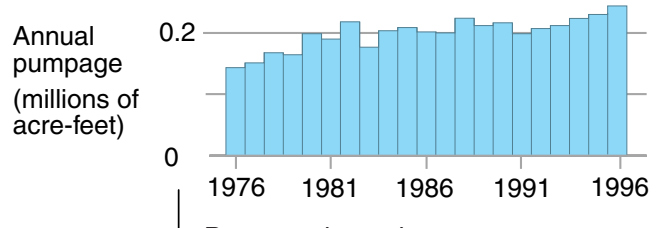
Pumpage in northwestern zones of the subsidence district
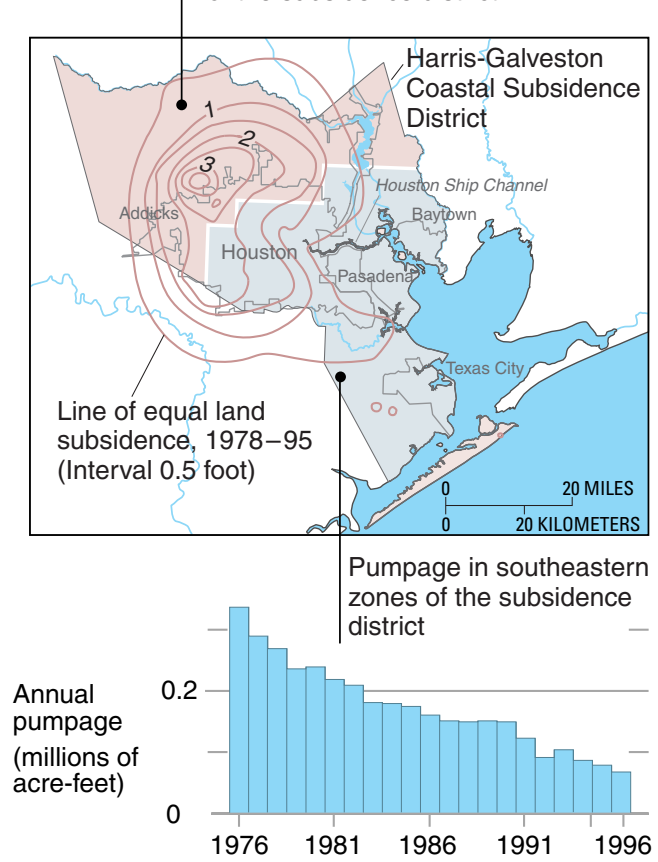

Source: Harris-Galveston Coastal Subsidence Distric

Figure 3. During 1978-95, subsidence in areas southeast of Houston essentially ceased as pumpage there decreased; and subsidence continued in areas northwest as pumpage there increased. combined effects of the eustatic sea-level rise and natural consolidation of the sediments along the Texas Gulf Coast yield a relative sea-level rise from natural causes that locally might exceed 0.08 inch (in.) per year (Paine, 1993). Although global warming is contributing to the presentday sea-level rise and might result in a sealevel increase of nearly 4 in. by 2050 (Titus and Narayanan, 1995), human-induced subsidence, by far, has been the dominant cause of relative sea-level rise along the Texas Gulf Coast during the 20th century, exceeding $1 \mathrm{in}$. per year throughout much of the affected area (Coplin and Galloway, 1999).

Galveston Bay is one of the most important bay ecosystems in the United States. The estuary is Texas' leading bay fishery, and it supports vibrant recreation and tourism industries. More than 60 percent of the bay's 232 miles (mi) of shoreline is composed of highly productive wetlands; because of subsidence, however, more than 26,000 acres of emergent wetlands have been converted to open water and barren flats (White and others, 1993). Subsidence also has contributed to an appreciable loss of submerged aquatic vegetation (mostly seagrass) since the 1950s. Some bay shorelines have become more susceptible to erosion by wave action because of loss of wetlands. As sea level rises, marshes along the shoreline are drowned. When development is located near the shoreline, the potential for the 


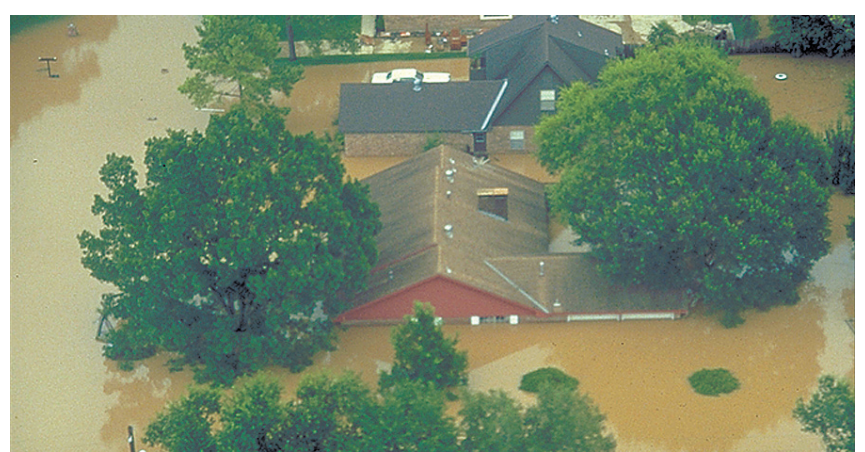

Figure 4. Land subsidence of 5 to 7 feet in a residential area in northern Houston exacerbated flooding in June 1989.

landward migration of marshes is greatly diminished. The result is a reduction in wetland habitats, habitats that provide the foundation for commercial and recreational fisheries.

The increasing demand for surface-water supplies, motivated in recent years by efforts to mitigate land subsidence, has led to construction of reservoirs and diversions that have reduced the sediments and nutrients transported to the bay system (Galveston Bay National Estuary Program, 1995). The natural processes in the bay and related ecosystems, which evolved with the rhythm of the unregulated streams and rivers, are affected. At the same time, the reduction in sediment inflows to the bay system resulting from construction of reservoirs along tributary rivers slows the natural rebuilding of shorelines. Because of the combined and interrelated effects of relative sea-level rise, loss of wetlands, and reduced sediment supply, the shoreline is eroding at an average rate of $2.4 \mathrm{ft}$ per year (Paine and Morton, 1986; Coplin and Galloway, 1999).

Subsidence exposes inland areas to increased risks of flooding and erosion by altering natural and engineered drainage-ways (open channels and pipelines) that depend on gravity-driven flow of storm runoff and sewage. Differential subsidence, depending on where it occurs with respect to the location of drainage-ways, might either reduce or enhance existing gradients. Gradient reduction decreases the rate of drainage and thereby increases the chance of flooding by stormwater runoff. Gradient reversal can result in ponding or backflow of sewage and stormwater runoff. In some areas, the drainage gradients might be increased and the rate of drainage thus increased. In terms of flooding risk, larger gradients might have a beneficial effect locally but have an adverse effect downstream. For open channels, the changing gradients alter streamflow characteristics, which leads to potentially damaging consequences of channel erosion and sediment deposition (Coplin and Galloway, 1999).

Subsidence in the greater Houston-Galveston Bay area is monitored because of the high risk of coastal and inland flooding, induction of fault movement, and adverse alteration of the Galveston Bay ecosystem. Ongoing patterns of subsidence in the Houston area are tracked using borehole extensometers, GPS and conventional spirit-leveling surveys, and more recently, InSAR.

\section{InSAR}

InSAR is a powerful new tool that uses radar (radio detecting and ranging) signals to measure displacement (subsidence and uplift) of the Earth's crust at an unprecedented level of spatial detail and high degree of measurement resolution. For landscapes that have more or less stable radar reflectors (such as buildings or other engineered structures, or undisturbed rocks and ground surfaces) over a period of time, it is possible to make high-precision measurements of the change in the position of the reflectors by subtracting or "interfering" the phase components of two radar scans made of the same area at different times. Interferograms- maps of relative surface displacement constructed from InSAR data-have demonstrated strong potential for high-density spatial mapping of ground-surface displacement (Galloway and others, 2000). Areas that include stable reflectors may appear as coherent or correlated colors or groups of colors in the interferogram. Areas that do not contain a sufficient number of stable reflectors are represented in the interferogram as many different uncorrelated colors and are described as incoherent or decorrelated.

The length of time between radar scans and errors owing to atmospheric disturbances are factors in developing coherent interferograms for the Houston-Galveston Bay area. Decorrelation over a fairly short time period most likely is caused by vegetation growth changing the reflective properties of the area being scanned (Zebker and Villasenor, 1992). Atmospheric disturbances caused by thunderstorms and high relative humidity are common in the Houston-Galveston Bay area and can affect the accuracy of the interferograms. Differences in water vapor content in the atmosphere over the areal extent of a single scan, or at the times of the two radar scans, can introduce errors of as much as 4 in. for range detection. In areas where there are differences in water vapor content, multiple interferograms can be averaged together to reduce errors (Zebker and others, 1997).

Two different satellite scenes (fig. 1) were needed to develop interferograms for the greater Houston-Galveston Bay area. Although most of the western interferogram, which spans the 11.5-month period January 13-December 29, 1996, is decorrelated, the western urbanized area of the greater metropolitan Houston area (fig. 5) is moderately coherent and has been unwrapped (that is, undergone processing to yield a continuous map of displacement where possible_-see box below) (fig. 6).

Most of the eastern Galveston Bay area interferogram, which spans the 31-month period August 27, 1996-March 29, 1999,

Phase shifts in the reflected radar result when the land surface changes position. The phase shifts ( 0 to $2 \pi)$ are scaled over one-half the wavelength of radar signal: from 0 to $1.10 \mathrm{in.}$ (28 millimeters [mm]) for the C-band radar of the European Remote Sensing 1 (ERS-1) and ERS-2 satellite platforms, which were used to develop the interferograms for the HoustonGalveston Bay area. The detected displacements are measured in the range direction of the radar of about $23^{\circ}$ from vertical for the ERS-1 and ERS-2 satellites, resulting in more sensitive measurements of vertical than horizontal land-surface displacements.

The interferogram is an image containing the detected phase shifts for each pixel (picture element, typically 30 or 90 meters square on the ground). Because the phase shifts are ambiguous-that is, shifts of $2 \pi, 4 \pi$, $6 \pi$, or equal fractions thereof are indistinguishablethe first product of the interferometric processing is termed the "wrapped" interferogram, which means the phase shifts from pixel to pixel are ambiguous and mapped with respect to a modulus of $2 \pi$. "Unwrapping" the phase shifts involves a separate processing procedure that results in a continuous map of phase shifts and thus displacement over the extent of the image where it is possible to resolve the potential ambiguities. The areas that are decorrelated, or where the data are not smooth and continuous, are not shown in the unwrapped interferogram. 


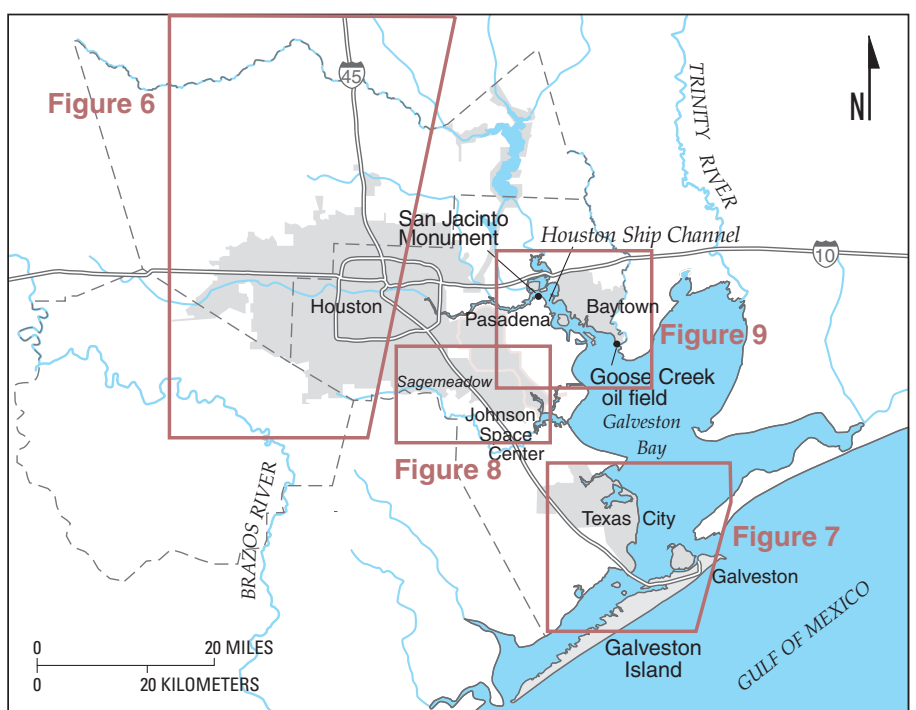

Figure 5. Areas of interferograms shown in figures 6-9.

also is decorrelated; however, three small areas (fig. 5) in the Galveston Bay area interferogram are coherent and have been unwrapped (figs. 7-9).

\section{InSAR-Detected Inland Subsidence, 1996}

The interferogram for the western Houston area shows a subsidence bowl in northwestern Harris County near Jersey Village that affects nearly $270 \mathrm{mi}^{2}$. The shape of the subsidence bowl is not clearly reflected in the subsidence contours for 1906-95 (fig. 2) but is reflected in the subsidence contours for 1978-95 (fig. 6). A clear relation exists between patterns of changes in aquifer hydraulic head in the Evangeline aquifer during 1977-97, overlain on the unwrapped interferogram, and the subsidence bowl. The pattern of the subsidence bowl in 1996 roughly corresponds to the pattern of head decline defined by the $-80-\mathrm{ft}$ contour (fig. 6).

The blue color south of Interstate Highway 10 on the wrapped interferogram is an area of zero subsidence as indicated by measurements from the Southwest extensometer for the same period as the interferogram. Because only the coherent parts of the interferogram were unwrappable, many patches of poor coherence are not included in the unwrapped interferogram, giving this image a "patchy" look. In the unwrapped interferogram, the color of zero subsidence is red at the site of the Southwest extensometer. Relative to this site, the maximum subsidence detected in the subsidence bowl is about 1.3 in. (about $35 \mathrm{~mm}$ ). (The use of dual units in this and the next section is intended to facilitate application of the data by maintaining the integrity of the processing units for InSAR, which are millimeters.) At the location of the Addicks extensometer, about 1 in. $(25 \mathrm{~mm})$ of subsid- ence is indicated in the interferogram, which compares favorably to the $1 \mathrm{in}$. $(25 \mathrm{~mm})$ measured by the Addicks extensometer for the same period.

\section{InSAR-Detected Coastal Subsidence, 1996-99}

In general, the Galveston Bay area interferogram is poorly correlated; however, three small areas (fig. 5) with good coherence show localized, small-magnitude deformation (subsidence and uplift). Although the magnitudes of uplift and subsidence in the interferograms for the three areas are near the minimum level of noise expected with the InSAR technology, $5 \mathrm{~mm}$ (Hoffmann and others, 2001), the general trends and magnitudes of displacement measured in the interferograms follow the general trends and magnitudes of displacement measured by the Texas CityMoses Lake, Clear Lake, Johnson Space Center, and Baytown extensometers.

The first Galveston Bay area unwrapped interferogram (fig. 7) shows small areas of coherence in Texas City and on Galveston Island. There might be some localized, small-magnitude, relative uplift in Texas City. The maximum uplift is less than 0.4 in. $(10 \mathrm{~mm})$ where a subsidence bowl (closed contour) is evident in the lines of equal subsidence for 1906-95. The Texas City-Moses Lake extensometer, located about $4.4 \mathrm{mi}$ from the localized relative uplift on the interferogram, measured 0.1 in. $(3 \mathrm{~mm})$ of subsidence near the northeastern edge of the coherent part of the interferogram. On Galveston Island there might be some small-magnitude subsidence, less than 0.4 in. $(10 \mathrm{~mm})$, on the bay side of the island relative to the ocean side in the coherent area.

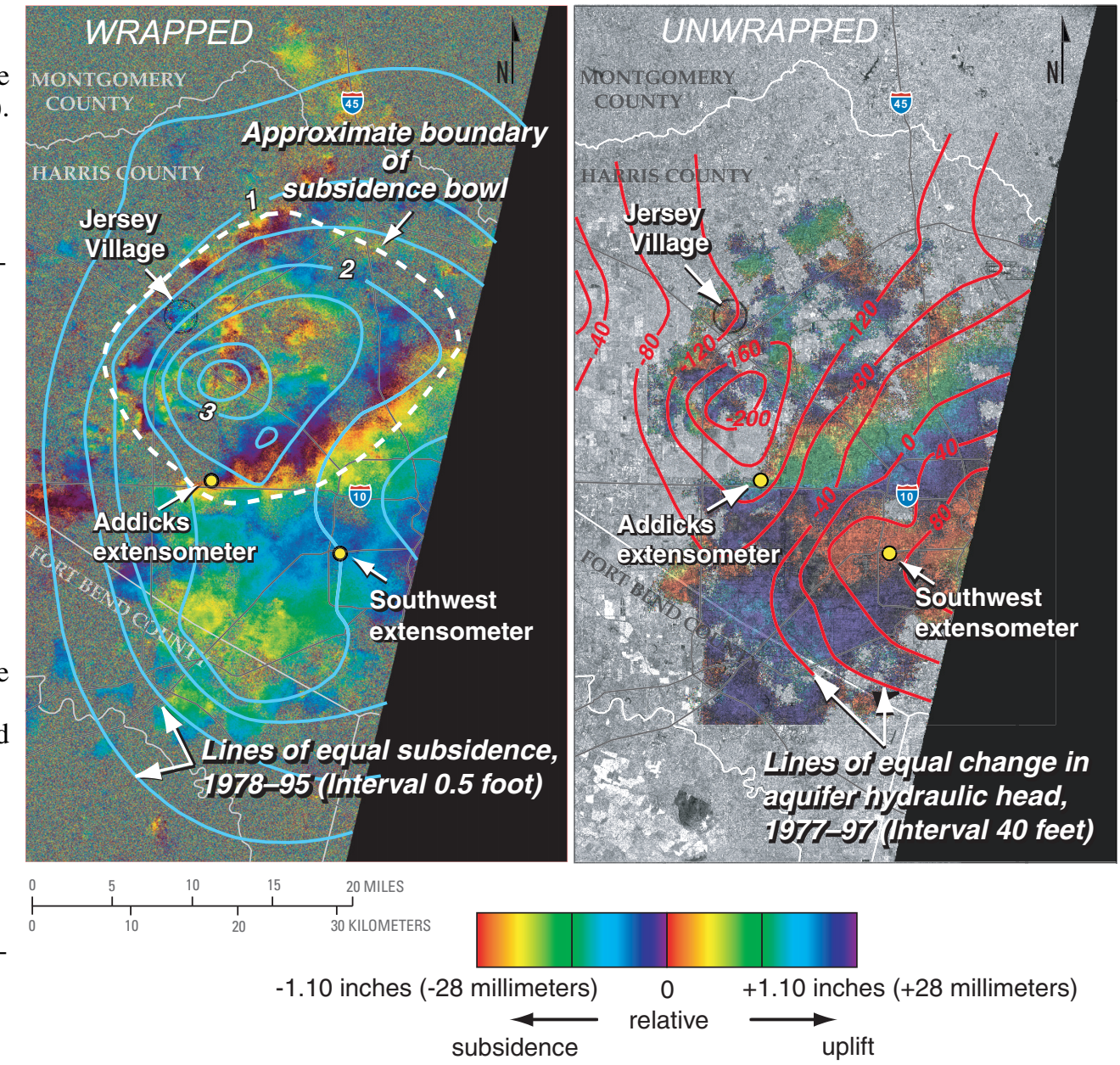

Figure 6. Wrapped and unwrapped interferograms for the western Houston area for the 11.5-month period January 13-December 29, 1996. 

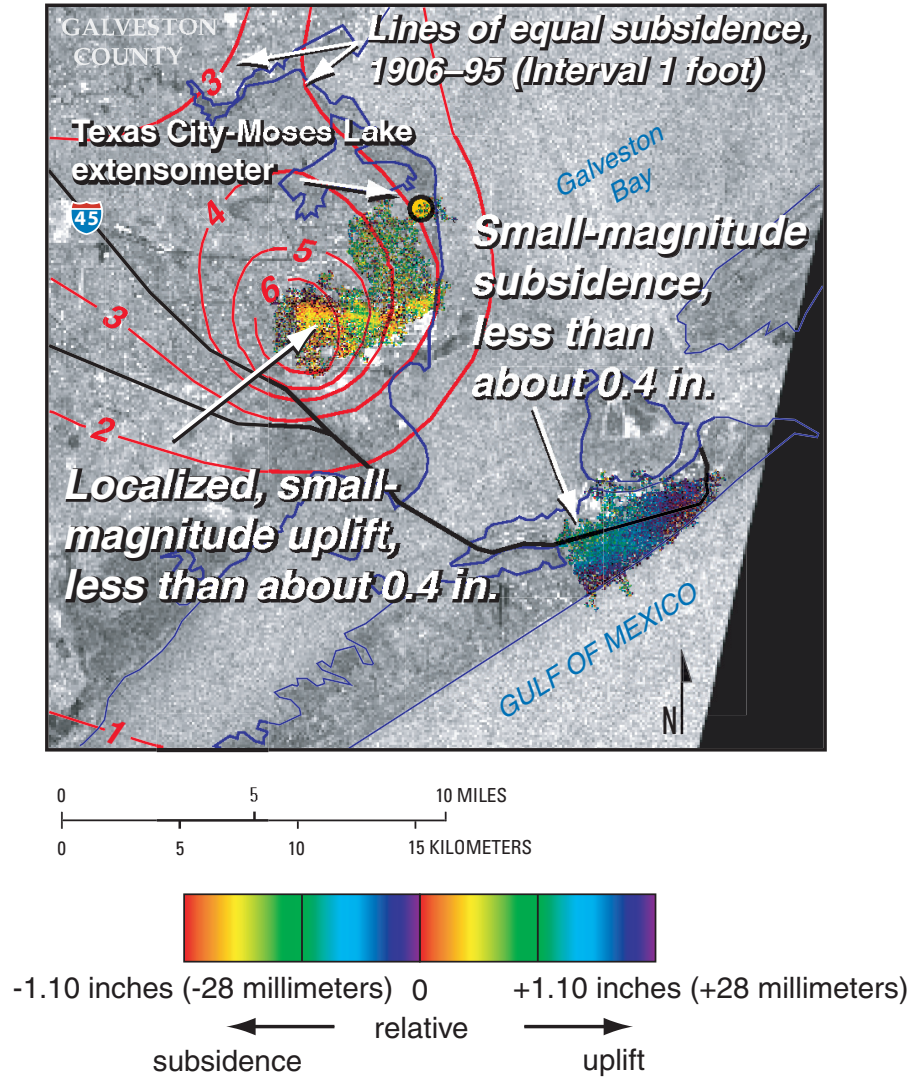

Figure 7. Unwrapped interferogram for the Texas City area for the 31-month period August 27, 1996-March 29, 1999.

Near the Johnson Space Center and in the Sagemeadow subdivision east of Clear Creek (fig. 8), about 0.4 to 0.8 in. (10 to $20 \mathrm{~mm}$ ) of localized subsidence might have occurred. During the same period $0.1 \mathrm{in} .(3 \mathrm{~mm})$ of subsidence was measured by the

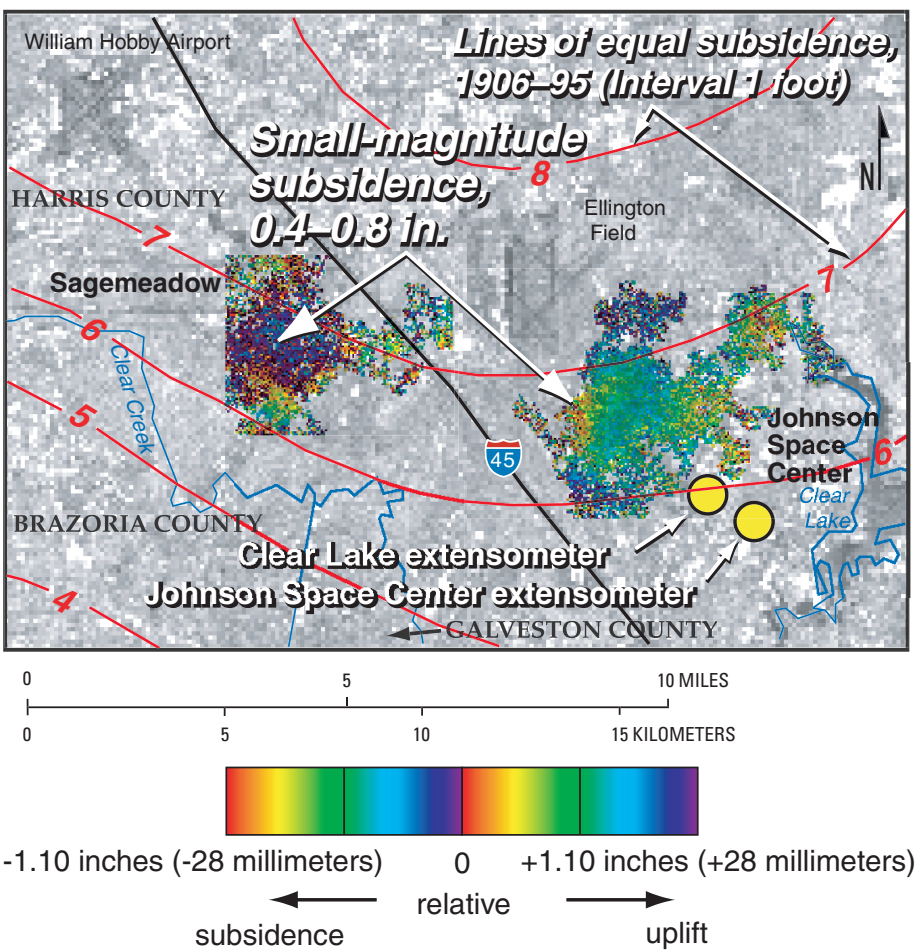

Figure 8. Unwrapped interferogram for the Sagemeadow-Johnson Space Center area for the 31-month period August 27, 1996-March 29, 1999.
Clear Lake extensometer, and $0.4 \mathrm{in} .(10 \mathrm{~mm})$ of subsidence was measured by the Johnson Space Center extensometer near the eastern edge of the eastern coherent area.

In the Baytown area where as much as $9 \mathrm{ft}$ of subsidence occurred during 1906-95, there might be 0.4 to 0.8 in. (10 to $20 \mathrm{~mm}$ ) of relative uplift (fig. 9). The Baytown extensometer measured 0.2 in. $(6 \mathrm{~mm})$ of uplift about $0.6 \mathrm{mi}$ northwest of the InSAR-detected uplift.

\section{Integrated Monitoring in the 21st Century}

In 1992, the Harris-Galveston Coastal Subsidence District adopted a regulatory action plan to reduce ground-water withdrawals. Currently (2002) the plan limits withdrawals in two of three areas (southeastern and central) that compose the district to specific percentages of each permittee's total water demand; the plan imposes increasingly stringent limits over time in the third (northwestern) area beginning in 2010 (Harris-Galveston Coastal Subsidence District, 1999). The decreasing subsidence rates or uplift observed at monitoring sites in the southeastern and central areas of the District are a direct result of reducing local groundwater withdrawals through conversion to imported surface-water supplies. In contrast, measurements from the northwesternmost part of the District show continuing subsidence as a result of continuing dependence on ground water (Coplin and others, 2001).

Ongoing patterns of subsidence in the Houston area are carefully monitored. Currently (2002) the USGS, in cooperation with the Harris-Galveston Coastal Subsidence District, measures compaction of subsurface material continuously using 13 borehole extensometers at 11 sites throughout the region. Piezometers completed to different depths are used to simultaneously monitor ground-water levels at each site. A network of 82 bench marks distributed throughout the Houston area was installed in 1987 for

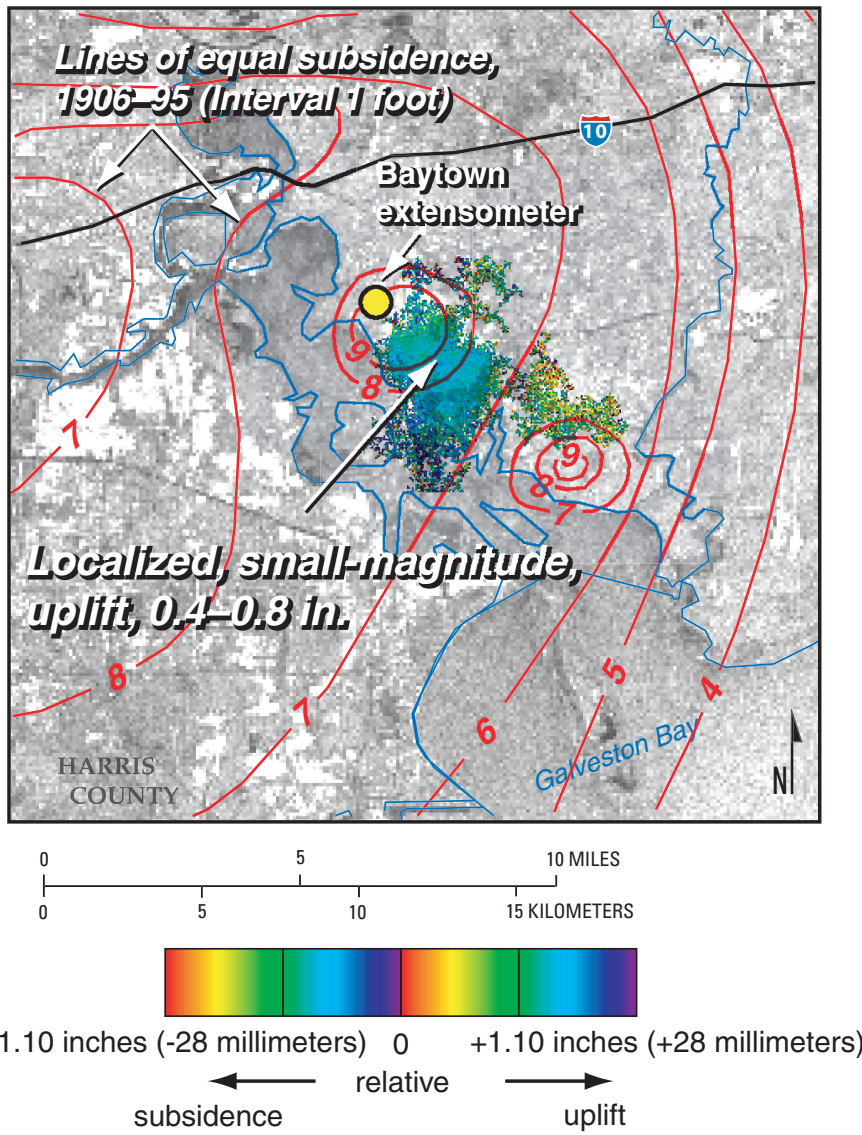

Figure 9. Unwrapped interferogram for the Baytown area for the 31-month period August 27, 1996-March 29, 1999. 
monitoring elevation changes using GPS; the bench marks were resurveyed in 1995 and 2000 and can be resurveyed any time to compute elevation changes for any time interval of interest. Continuous-operating GPS reference stations are used to monitor the elevation of three extensometers. In addition to these three fixed locations, portable GPS receivers mounted in trailers (Port-AMeasures or PAMs) are used wherever subsidence measurements are needed. The PAMs routinely operate at four different sites each month, occupying each site for 1 week before being moved to the next site. InSAR is used to produce spatially detailed displacement maps that complement the sparse point measurements of GPS receivers and extensometers; measurements using InSAR have been shown to be consistent with GPS and extensometer measurements.

The operational lifetime of a remote-sensing satellite typically is about 5 years. ERS-1 is no longer operational; ERS-2 is still collecting radar data, although most data acquired since late 2000 are not suitable for interferometry because of navigation uncertainties. The European Space Agency launched ENVISAT in March 2002, and radar data potentially will be acquired and processed to develop InSAR land-surface displacement maps for various time intervals of interest, subject to data availability and quality.

Interferograms cannot be created by combining ERS and ENVISAT data because data from the two types of platforms are incompatible. There is an InSAR component to a project named EarthScope currently being proposed by a consortium of U.S. scientists and agencies including the National Science Foundation, USGS, and National Aeronautics and Space Administration. The project plan tentatively schedules the launch of the radar platform in 2007, although the project has not yet been funded.

The low elevation, proximity to bays and the Gulf of Mexico, dense population, and large capital investment make it likely that the Houston-Galveston Bay area has been affected more substantially by subsidence than any other metropolitan area in the United States. Houston's continuing growth means that subsidence will continue to be vigilantly monitored and managed. InSAR is a valuable new tool that can be used in the urban Houston and Galveston Bay area to monitor large areas with a high degree of spatial resolution at a relatively low cost.

\section{- S.V. Stork and M. Sneed}

(Radar data used to produce the interferograms shown in this fact sheet were obtained from the European Space Agency, distributed through Eurimage Corporation for purposes of research and development. Images were smoothed using a filtering program written by Zhong Lu, Ratheon Information Technology and Scientific Services, USGS Earth Resources Observation Systems Data Center.)

\section{Selected References}

Centre National d'Etudes Spatiales, 1997, PRISME/DIAPASON software, version 1.0: Toulouse, France.

Coplin, L.S., and Galloway, D.L., 1999, Houston-Galveston, TexasManaging coastal subsidence, in Land subsidence in the United States: U.S. Geological Survey Circular 1182, p. 35-48.

Coplin, L.S., Houston, N.A., and Brown, D.W., 2001, Water-level altitudes 2001, water-level changes 1977-2001 and 2000-2001, and compaction 1973-2000 in the Chicot and Evangeline aquifers Houston-Galveston region, Texas: U.S. Geological Survey OpenFile Report 01-094, 8 sheets.

Gabrysch, R.K., 1983, The impact of land-surface subsidence, in Impact of Science on Society, Managing our Fresh-Water Resources: United Nations Educational, Scientific and Cultural Organization No. 1, p. $117-123$.

*Galloway, D.L., Jones, D.R., and Ingebritsen, S.E., eds., 1999, Land subsidence in the United States: U.S. Geological Survey Circular $1182,177 \mathrm{p}$. http://water.usgs.gov/pubs/circ/circ1182/

* _ 2000, Measuring land subsidence from space: U.S. Geological Survey Fact Sheet 051-00, 4 p. http://water.usgs.gov/pubs/FS/fs-051-00/pdf/fs-051-00.pdf

Galveston Bay National Estuary Program, 1995, The Galveston Bay plan-The comprehensive land management plan for the Galveston Bay ecosystem, Oct. 18, 1994: Galveston Bay National Estuary Program Publication GBNEP-49, $457 \mathrm{p}$.

Harris-Galveston Coastal Subsidence District, 1999, District regulatory plan, 1999: Friendswood, Tex., 17 p.

Hoffmann, Jörn, Zebker, H.A., Galloway, D.L., and Amelung, Falk, 2001, Seasonal subsidence and rebound in Las Vegas Valley, Nevada, observed by synthetic aperture radar interferometry: Water Resources Research, v. 37, no. 6, p. 1,551-1,566.

Holzer, T.L., and Gabrysch, R.K., 1987, Effect of water-level recoveries on fault creep, Houston, Texas: Ground Water, v. 25, no. 4, p. 392-397.

Paine, J.G., 1993, Subsidence of the Texas coast-Inferences from historical and late Pleistocene sea levels: Tectonophysics, v. 222, p. $445-458$.

* Suggested further reading.

Paine, J.G., and Morton, R.A., 1986, Historical shoreline changes in Trinity, Galveston, West, and East Bays, Texas Gulf Coast: University of Texas, Bureau of Economic Geology Circular 86-3, $58 \mathrm{p}$.

* Parashar, Surendra, 2001, Overview of spaceborne SAR programs, in U.S. Government Synthetic Aperture Radar (SAR) Users Symposium, Washington, D.C., Mar. 28-29, 2001: U.S. National Oceanic and Atmospheric Administration and Canadian Space Agency. http://orbit-net.nesdis.noaa.gov/orad/sarconference/ SpaceborneSARprograms.pdf

*Rosen, P.A., Hensley, S., Joughin, I.R., Li, F.K., Madsen, S.N., Rodriguez, E., and Goldstein, R.M, Synthetic aperture radar interferometry, 2000: Proceedings of the Institute of Electrical and Electronics Engineers, v. 88, no. 3, p. 333-382.

State of Texas, 1975, General and special laws of the State of Texas passed by the regular session of the Sixty-Fourth Legislature: State of Texas, chap. 284, p. 672-684.

Titus, J.G., and Narayanan, V.K., 1995, The probability of sea level rise: U.S. Environmental Protection Agency, EPA 230-R-95-008.

White, W.A., Tremblay, T.A., Wermund, E.G., Jr., and Handley, L.R., 1993, Trends and status of wetland and aquatic habitats in the Galveston Bay system, Texas: Galveston Bay National Estuary Program Publication GBNEP-31, 225 p.

Zebker, H.A., Rosen, P.A., Hensley, S., 1997, Atmospheric artifacts in interferometric synthetic aperture radar surface deformation and topographic maps: Journal of Geophysical Research, v. 102, p. $7,547-7,563$.

Zebker, H.A., Villasenor, J., 1992, Decorrelation in interferometric radar echoes: Institute of Electrical and Electronics Engineers Transactions on Geoscience and Remote Sensing, v. 30, p. 950-959.

Any use of trade, product, or firm names is for descriptive purposes only and does not imply endorsement by the U.S. Government.

For more information on this study or subsidence in the Houston area, contact

Subdistrict Chief

U.S. Geological Survey

2320 La Branch St., Ste. 1112

Houston, TX 77004

E-mail: dc_tx@usgs.gov
Phone: (713) 718-3655

World Wide Web:

http://tx.usgs.gov/ 